\title{
Processing of $\beta$-Amyloid Precursor Protein in Microglia and Astrocytes Favors an Internal Localization over Constitutive Secretion
}

\author{
Christian Haass, Albert Y. Hung, and Dennis J. Selkoe \\ Department of Neurology and Program in Neuroscience, Harvard Medical School and Center for Neurologic Diseases, \\ Brigham and Women's Hospital, Boston, Massachusetts 02115
}

\begin{abstract}
Microglial cells and astrocytes are closely associated with nearly all compact deposits of the amyloid $\beta$-protein found in the senile plaques characteristic of Alzheimer's disease and trisomy 21 . The biosynthesis and metabolic fate of the $\beta$-amyloid precursor protein ( $\beta$ APP) in astrocytes has not been characterized, and its identification in microglia has not been described. Here, we report the expression of $\beta$ APP by astrocytes and microglia in primary cultures of cerebral cortex from newborn rats. Using metabolic labeling followed by immunoprecipitation, we show that both astrocytes and microglia express substantial amounts of the major isoforms of $\beta$ APP. This is confirmed by PCR-mediated amplification of the corresponding mRNAs, showing that all three major transcripts $\left(\beta_{\mathrm{APP}}{ }_{695}, \beta \mathrm{APP}_{751}\right.$, and $\left.\beta \mathrm{APP}_{770}\right)$ are present in relatively equal amounts. Despite rapid turnover of the precursor, astrocytes and microglia show a reduced production of soluble fragments of $\beta$ APP compared to celis transfected with $\beta$ APP cDNAs. The relative amount of soluble $\beta$ APP molecules generated is both cell type and isoform specific. Immunocytochemistry reveals that full-length $\beta$ APP is located in internal membranous vesicles, with only very little insertion at the cell surface. The latter data are in agreement with the reduced ability of microglia and astrocytes to cleave the BAPP into soluble derivatives. Our findings indicate that both astrocytes and microglia strongly express all three major forms of $\beta$ APP but apparently process these molecules by an alternative pathway that generates very small amounts of soluble $\beta$ APP. The immunocytochemical localization and the biochemical data lead to the suggestion that $\beta$ APP may not function principally as a cell surface or secreted protein in vivo but may have an important intracellular function.
\end{abstract}

The $\beta$-amyloid precursor protein ( $\beta \mathrm{APP}$ ) is a widely expressed membrane-spanning glycoprotein, isoforms of which arise by alternative splicing of a pre-mRNA transcribed from a gene on

\footnotetext{
Received Mar. 28, 1991; revised July 3, 1991; accepted July 7, 1991.

We thank M. Graeber for help in preparation of the primary glial cultures, $\mathrm{G}$. Lee for useful suggestions on immunocytochemical techniques, A. Caceres for the introduction to culturing of primary neurons, and B. Ostazewski and M. Podlisny for help in producing antibody $\alpha \mathrm{R} 1285$. We are grateful to B. Yankner and M. Graeber for critical review of the manuscript, and to $K$. Rosen and members of our laboratory for helpful discussions. This work was supported by NIH Grants AG07911 (LEAD Award) and AG06173 (D.J.S.), a McKnight Neuroscience Rescarch Award (D.J.S.), and fellowships from Bochringer Ingelhcim Stipendicnfond (C.H.) and Merck Sharp and Dohme Research Laboratories (A.Y.H.)

Correspondence should be addressed to Dennis J. Selkoe, Center for Neurologic Diseases, Brigham and Women's Hospital, Boston, MA 02115.

Copyright (C) 1991 Society for Neuroscience $0270-6474 / 91 / 113783-11 \$ 05.00 / 0$
}

human chromosome 21 . The initial cloning (Kang et al., 1987) and characterization of $\beta$ APP followed the identification of an $\sim 40$ residue fragment, the amyloid $\beta$-protein $(\mathrm{A} \beta \mathrm{P})$, as the subunit of the amyloid fibrils that are progressively deposited in meningocerebral blood vessels (Glenner and Wong, 1984) and cerebral plaques (Masters et al., 1985b; Selkoe et al., 1986) in Alzheimer's disease and trisomy 21. $\beta$ APP mRNAs and proteins have been detected in many mammalian tissues and cell lines (see, e.g., Goldgaber et al., 1987; Robakis et al., 1987; Tanzi et al., 1987; Neve et al., 1988; Selkoe et al., 1988; Tanaka et al., 1989; Weidemann et al., 1989), and the molecule shows a high degree of evolutionary conservation (Yamada et al., 1987; Shivers et al., 1988; Podlisny et al., 1991).

In addition to the initially cloned 695 residue isoform $\left(\beta \mathrm{APP}_{695}\right)$, three alternative transcripts $\left(\beta \mathrm{APP}_{563}, \beta \mathrm{APP}_{751}\right.$, and $\beta A P_{770}$ ) have been identified that contain an inserted exon having $\sim 50 \%$ homology with the Kunitz family of serine protease inhibitors (Kitaguchi et al., 1988; Ponte et al., 1988; Tanzi et al., 1988; De Sauvage and Octave, 1989). Several putative functions have been ascribed to $\beta$ APP or its proteolytic fragments based on in vitro studies, including inhibition of extracellular serine proteases (Van Nostrand and Cunningham, 1987; Kitaguchi et al., 1988; Sinha et al., 1990). Indeed, constitutive cleavage of $\beta$ APP (Esch et al., 1990; Sisodia et al., 1990) gives rise to a large soluble form $(\sim 100 \mathrm{kDa})$ identical to protease nexin II (PN-II) (Oltersdorf et al., 1989; Van Nostrand et al., 1989), lcaving an $-10 \mathrm{kDa}$ fragment retained within the membrane (Selkoe et al., 1988). In addition, other proposed functions for $\beta$ APP based on in vitro studies include an autocrine or growthpromoting function (Saitoh et al., 1989), participation in cell adhesion as an extracellular matrix protein (Schubert et al., 1989a), inhibition of coagulation factor XIa (Smith et al., 1990), and as a cell surface receptor (Kang et al., 1987).

There is great interest in the role of the A $\beta P$ fragment of $\beta$ APP in the pathogenesis of Alzheimer's disease, particularly in view of recent observations that amorphous, largely nonfilamentous deposits of $\mathrm{A} \beta \mathrm{P}$ may precede the development of the other cytopathological lesions of Alzheimer's disease and trisomy 21 by years or decades (see, e.g., Tagliavini et al., 1988; Yamaguchi et al., 1988; Giaccone et al., 1989; Joachim et al., 1989b,c; Motte and Williams, 1989; Rumble et al., 1989; for review, see Selkoe, 1989). The apparent early deposition of $A \beta P$ focuses increased attcntion on the unresolved question of which cells produce the $\beta$ APP molecules that are alternatively processed to release the $\mathrm{A} \beta \mathrm{P}$ peptide. The juxtaposition of $\beta \mathrm{APP}$-rich neuronal cell bodies and neurites to cortical $\mathrm{A} \beta \mathrm{P}$ plaques has fueled interest in 
the hypothesis that neurons are the source of $\beta$-amyloid (Masters et al., 1985a; Koo et al., 1990). The occurrence of many microvascular deposits of $\mathrm{A} \beta \mathrm{P}$, including in meningeal arteries outside the brain parenchyma, has supported the notion that vessel wall- or blood-derived cells could produce the amyloidogenic peptides (Joachim et al., 1989a; Selkoe, 1989). Besides these potential sources, it is known that reactive astrocytes and activated microglia are intimately associated with $\mathrm{A} \beta \mathrm{P}$ deposits in most mature ("classical") and some immature ("diffuse") plaques (see, e.g., Schechter et al., 1981; Probst et al., 1987; Itagaki et al., 1989; Rozemuller et al., 1989; Wisniewski et al., 1989). The detection of $\beta$ APP proteins and mRNAs in cerebral astrocytes both in situ (Card et al., 1988; Siman et al., 1989; Golde et al., 1990) and in vitro (Berkenbosch et al., 1990; Ohyagi et al., 1990) has suggested that plaque-associated astrocytes could serve as a source of $\mathrm{A} \beta \mathrm{P}$ in Alzheimer's disease. Berkenbosch and colleagues reported that type I astrocytes in primary mixed glial cultures of $2-3$-d-old rats produced only $\beta \mathrm{APP}_{695}$; no KPIcontaining forms of $\beta$ APP were detected by Northern and Western blotting or immunocytochemistry. This result is surprising, since all other non-neuronal and neuronal cells reported to date have been found to express some $\beta A P P_{751}$. The identification and characterization of $\beta$ APP in microglial cells have not been reported.

In this study, we report the substantial expression of all three major forms of $\beta$ APP $(695,751$, and 770) in both astrocytes and microglia cultured from newborn rat cerebral cortex. Biosynthetic labeling and immunoprecipitation reveal that these $\beta$ APP isoforms are rapidly turned over, yet relatively small amounts of the constitutively cleaved, soluble amino-terminal fragment are secreted into the media. PCR-mediated amplification of the corresponding mRNAs shows that all three transcripts occur in rather equal amounts. Immunocytochemistry localizes full-length $\beta$ APP to membranous cytoplasmic organelles, particularly perinuclear vesicles, with very little insertion at the cell surface. In addition, we show that the relative production of soluble isoforms of $\beta$ APP is dependent on the cell type and isoform analyzed. Taken together, our data indicate that both astrocytes and microglia produce substantial amounts of all three $\beta$ APP isoforms but process some of these molecules by a mechanism other than the constitutive proteolytic pathway identified in other cell types.

\section{Materials and Methods}

Preparation of primary cell cultures. Primary source cultures of rat glial cells were prepared as described by McCarthy and de Vellis (1980), with minor modifications. Briefly, the cerebral cortices of 1-2-d-old rats (Charles River Breeding Labs, Wilmington, MA) were dissected, and the meninges were removed. The tissue was trypsinized $(0.25 \%$ for 20 min), mechanically dissociated by repeated passage through a Pasteur pipette, and directly plated into flasks containing Dulbecco's modified Eagle's medium (DMEM) (GIBCO Laboratories, Grand Island, NY) supplemented with $10 \%$ fetal calf serum (Sigma Chemical Co., St. Louis, $\mathrm{MO}$ ). Cells were maintained in a humidified incubator at $37^{\circ} \mathrm{C}, 5 \% \mathrm{CO}_{2}$ for 2-3 weeks.

From these source cultures, microglial cells were isolated as previously described (Graeber et al., 1989), as modified from the methods of Frei et al. (1987) and Giulian and Baker (1986). Cells growing on top of a confluent cell layer were removed by vigorous agitation and plated either into $6 \mathrm{~cm}$ plastic dishes or onto polylysine-coated glass coverslips. After $30 \mathrm{~min}$, nonadherent cells were removed and fresh culture medium was added. For immunofluorescence, microglia were plated at a density of $\sim 5-10 \times 10^{3} \mathrm{cells} / \mathrm{cm}^{2}$. After $1-2 \mathrm{~d}$, cells were processed for further analysis as described below.
Pure populations of astrocytes were obtained using a modification of the method of McCarthy and de Vellis (1980). Source cultures were shaken overnight at $250 \mathrm{rpm}$ at $37^{\circ} \mathrm{C}$. Medium containing loose cells was removed, and the remaining cell layer was trypsinized and replated onto either plastic dishes or polylysine-coated coverslips. For immunofluorescence, cells were grown for at least 2-3 d before fixation.

Hippocampal neurons were prepared from the brains of 17-18-d-old rat fetuses, as described by Banker and Cowan (1977) and Bartlett and Banker (1984). Hippocampi were trypsinized $\left(0.25 \%, 15 \mathrm{~min}\right.$ at $\left.37^{\circ} \mathrm{C}\right)$, washed with $\mathrm{Ca}$ - and $\mathrm{Mg}$-free Hanks' balanced salt solution, and dissociated by passage through a Pasteur pipette. The cell suspension was plated at very high density into polylysine-coated $60 \mathrm{~mm}$ dishes (1-2 $\times 10^{\circ}$ cells/dish) with DMEM containing $10 \%$ horse serum. After $3 \mathrm{hr}$ at $37^{\circ} \mathrm{C}$, the medium was removed, and the cultures were maintained in DMEM supplemented with the N2 mixture of Bottenstein and Sato (1979) for 3-4 d.

Antibodies against $\beta$-amyloid precursor protein. Antibody $\alpha \mathrm{R} 1285$ was produced against a synthetic peptide corresponding to residues $527-$ 540 of $\beta \mathrm{APP}_{695}$ (numbering of Kang et al., 1987) and is similar to antibody R36 raised by Ishii et al. (1989) to the same sequence. This polyclonal antiserum was prepared as previously described (Selkoe et al., 1988). To recognize C-terminal epitopes, antibody $\alpha \mathrm{C} 7$ raised against a synthetic peptide of the last 20 amino acids of $\beta$ APP (Podlisny et al., 1990 ) was used. For affinity purification of $\alpha \mathrm{R} 1285$ and $\alpha \mathrm{C} 7$, the corresponding peptides were coupled to a mixture of Affigel-10 and Affigel15 (Bio-Rad, Richmond, CA) according to the protocol of the manufacturer. The antibodies were bound overnight at $4^{\circ} \mathrm{C}$. Proteins bound nonspecifically were removed by washing the column with $20 \mathrm{vol}$ of $0.3 \mathrm{~m}$ Tris-buffered saline (TBS; $10 \mathrm{~mm}$ Tris, pH 7.6, $0.3 \mathrm{M} \mathrm{NaCl}, 0.3 \%$ Triton X-100), after which the column was washed with 2 vol of PBS to remove residual Triton $\mathrm{X}-100$. The affinity-purified antibodies were then eluted with 2.5 vol of $0.2 \mathrm{M}$ glycine $(\mathrm{pH} 2.5$ ) and immediately neutralized with Tris. The specificity of the affinity-purified antibodies was tested by immunoblotting (data not shown). Monoclonal antibody (mAb) 22C11 (Boehringer Mannheim, Indianapolis, IN) was used to label N-terminal epitopes of $\beta$ APP specifically.

Gel electrophoresis and immunoblotting. Total cell extracts were prepared according to Weidemann et al. (1989). These extracts were separated on $7.5 \%$ and $10 \%$ polyacrylamide gels (Laemmli, 1970) and transferred to nitrocellulose filters using standard conditions. For immunoblotting, membranes were blocked for $1 \mathrm{hr}$ in $50 \%$ horse serum in TBS (10 mM Tris, pH 7.6, $140 \mathrm{~mm} \mathrm{NaCl}$ ) followed by a $1 \mathrm{hr}$ incubation with the antiserum. Filters were washed $3 \times 20 \mathrm{~min}$ in $0.5 \mathrm{M}$ TBS (10 mm Tris, $\mathrm{pH} 7.6,0.5 \mathrm{M} \mathrm{NaCl}, 0.5 \%$ Triton $\mathrm{X}-100$ ). The alkaline phosphatase-coupled secondary antibody (Promega Corp., Madison, WI) was used in a 1:7500 dilution in TBS, 5\% horse serum. After a $1 \mathrm{hr}$ incubation, filters were washed as described above. Color development was done according to standard conditions.

Metabolic labeling and immunoprecipitation. For metabolic labeling, $\beta A P P-t r a n s f e c t e d$ human 293 kidney cells (Selkoe et al., 1988; Oltersdorf et al., 1989) and astrocytes were grown to about $90 \%$ confluence in $6 \mathrm{~cm}$ dishes. Microglial cells were plated to about $90 \%$ confluence. After removal of culture medium, $2 \mathrm{ml}$ of methionine-free DMEM were added, and the cells were labeled for $12 \mathrm{hr}$ with $150 \mu \mathrm{Ci} \mathrm{L}^{-35} \mathrm{~S}$-methionine (New England Nuclear, Boston, MA). Preparation of cell extracts was done as described above. For analysis of soluble forms of $\beta$ APP, the medium was centrifuged at $10,000 \times g$ in a Sorvall HB4 rotor for $1 \mathrm{hr}$. The supernatant was carefully removed and used for immunoprecipitation. Immunoprecipitations from cell extracts or media were carried out according to Weidemann et al. (1989) with the following modifications: immunoprecipitates were washed three times for 20 min each at $4^{\circ} \mathrm{C}$ in $0.5 \mathrm{M}$ STEN [ $50 \mathrm{~mm}$ Tris, pH 7.5, $0.5 \mathrm{M} \mathrm{NaCl}, 2 \mathrm{~mm}$ EDTA, $0.2 \%$ Nonidet P-40 (NP-40)], SDS-STEN (50 mM Tris, pH 7.5, $150 \mathrm{~mm}$ $\mathrm{NaCl}, 2 \mathrm{~mm}$ EDTA, 0.1\% SDS), and STEN (50 mM Tris, pH 7.5, 150 mM NaCl, 2 mм EDTA, 0.2\% NP-40). The buffers were supplemented with $2 \mathrm{~mm}$ phenylmethylsulfonyl fuoride and $50 \mu \mathrm{g} / \mathrm{ml}$ leupeptin. Immunoprecipitated proteins were separated on $10 \%$ polyacrylamide gels and fixed in Coomassie blue. After incubation of the gel in Enhance (New England Nuclear), labeled proteins were visualized by autoradiography. For immunoprecipitations, we used the number of dishes described in Results. One $6 \mathrm{~cm}$ dish contained about 2-3 $\times 10^{6}$ kidney 293 cells, about $1.5 \times 10^{6}$ astrocytes, or about $1 \times 10^{6}$ microglial cells. For pulse-chase experiments, astrocytes were pulse labeled with 150 $\mu \mathrm{Ci}$ of $\mathrm{L}_{-}{ }^{35} \mathrm{~S}$-methionine for $20 \mathrm{~min}$ followed by the indicated chase periods using media containing an excess of unlabeled methionine. For 
each time point, $3 \times 10^{6}$ astrocytes were labeled. Immunoprecipitations were performed as described above using antibody $\alpha \mathrm{C} 7$.

Isolation of total RNA and PCR amplification of $m R N A$. Total RNA was isolated from tissue culture cells using the guanidinium-thiocyanate procedure (Maniatis et al., 1989). For PCR-mediated amplification of human $\beta$ APP mRNAs, we used the following oligonucleotide primers: K.PI-R, which corresponds to the reverse sequence of $\beta$ APP (Kang et al., 1987) between base pairs (bp) 921 and 901 (GGCGGATCCAGGTGTCTTCGAGATACTTGT), and KPI-F between bp 834 and 853 (GGCGAATTCACCACAGAGTCTGTGGAAG) (Podlisny et al., 1991). The corresponding rat-specific primers were KPI-R rat (GGCGGATCCGGGGGTCTCCAGGTACTTGT) and KPI-F rat (GGCGAATTCTACCACTGAGTCTGTGGAGG) according to the sequence published by Shivers et al. (1988). The KPI-F primers contained an EcoRI restriction site at the 5 ' end, and the KPI-R primers contained a BamHI restriction site (underlined in the sequences).

For first-strand cDNA synthesis, we used $1 \mathrm{ng}$ of the KPI-R primer in a mix containing $1 \mu \mathrm{g}$ of total RNA, $0.5 \mu \mathrm{l}$ of RNasin (Promega), $19.5 \mathrm{U}$ of reverse transcriptase, and $1.25 \mathrm{~mm}$ dNTP mix in $1 \times$ reverse transcriptase buffer. The reaction was incubated at $37^{\circ} \mathrm{C}$ for $1 \mathrm{hr}$. Five microliter aliquots of these reactions were used in PCR reactions (Saiki et al., 1988).

Immunocytochemistry. Cells plated onto glass coverslips were fixed in $-20^{\circ} \mathrm{C}$ methanol for $10 \mathrm{~min}$, followed by brief fixation in acetone $(50 \%, 2 \mathrm{~min} ; 100 \%, 3 \mathrm{~min} ; 50 \%, 2 \mathrm{~min})$. Nonspecific binding of primary antibody was blocked by incubation in PBS containing $2 \%$ goat serum for $60 \mathrm{~min}$ at $37^{\circ} \mathrm{C}$. The cells were then incubated with primary antibody either at $37^{\circ} \mathrm{C}$ for $3 \mathrm{hr}$, or at $4^{\circ} \mathrm{C}$ overnight. After five $5 \mathrm{~min}$ washes in PBS, the appropriate secondary antibody [tetramethylrhodamine isothiocyanate (TRITC)-conjugated goat anti-rabbit IgG, fluorescein isothiocyanate (FITC)-conjugated goat anti-mouse IgG, Boehringer Mannheim] was added for $60 \mathrm{~min}$ at room temperature. Coverslips were then washed as before. To confirm identification of the microglial cells, a monoclonal antibody against rat macrophage surface antigen CR3 (OX42; Accurate Chemical and Scientific, Westbury, NY) was used. Astrocyte identity was confirmed with a polyclonal antiserum raised against glial fibrillary acidic protein (GFAP) (the kind gift of Dr. D. Dahl, West Ruxbury V. A. Medical Center, Buston, MA).

To label specifically epitopes present on the cell surface, we used the double-labeling method described by Bakke and Dobberstein (1990), with modifications. Cells plated on polylysine-coated coverslips were incubated with $\mathrm{mAb} 22 \mathrm{Cl1}$ for $1 \mathrm{hr}$ on ice and washed five times for 3 min each in PBS containing 2\% horse serum (PBS-HS). All subsequent washes were carried out in like manner. The cells were then labeled with FITC-conjugated goat anti-mouse IgG for $45 \mathrm{~min}$ on ice. After washing with PBS-HS, the cells were fixed with $4 \%$ paraformaldehyde, $0.12 \mathrm{M}$ sucrose for $20 \mathrm{~min}$ at room temperature, followed by $0.1 \mathrm{M}$ glycine for 5 min to block remaining paraformaldehyde activity. The cells were then permeabilized with $0.1 \%$ Triton $X-100$ for $5 \mathrm{~min}$ at room temperature and washed with PBS-HS. Incubations with a second $\beta$ APP antibody, $\alpha \mathrm{C} 7$, and its corresponding secondary antibody were done at room temperature for $60 \mathrm{~min}$ and $45 \mathrm{~min}$, respectively. The converse experiment was also performed. As a control for specific antibody labeling of antigens either on the cell surface or within the cell, $\mathrm{mAb}$ OX42 was applied to cultured microglia either before or after fixation and Triton permeabilization.

\section{Results}

\section{Detection of $\beta A P P$ in cultured astrocytes and microglia}

In order to characterize the expression of $\beta A P P$ in astrocytes and microglial cells, we established primary tissue cultures from the cerebral cortex of newborn rats. From these cultures, we isolated essentially pure populations of microglia and astrocytes. Ameboid microglia were identified based on their staining with a monoclonal antibody (OX42) against the rat macrophage surface antigen CR3 (C3bi complement receptor) (Robinson et al., 1986). Furthermore, these cells were peroxidase negative, distinguishing them from peripheral macrophages or monocytes (Giulian and Baker, 1986). Astrocyte cultures were confirmed to be GFAP positive by immunostaining. Both $\mathrm{CR} 3(+) \mathrm{mi}-$ croglial cultures and GFAP(+) astrocyte cultures in these purified cell populations were greater than $95 \%$ pure, based on immunocytochemistry (data not shown).

Identical amounts of total cell homogenates of both cell types were prepared and immunoblotted with a high-titer antiserum $(\alpha C 7)$ produced to a synthetic peptide of amino acids 676-695 of $\beta$ APP (Podlisny et al., 1990). As a control in this and all further experiments, we examined human embryonic kidney 293 cells stably transfected with cDNAs coding for $\beta \mathrm{APP}_{695}$ (Selkoe et al., 1988) or $\beta \mathrm{APP}_{751}$ (Oltersdorf et al., 1989). As shown in Figure $1 a, \alpha \mathrm{C} 7$ identifies full-length $\beta \mathrm{APP}$ in all cell types analyzed; the migration of these bands is consistent with previously published results on other cells and tissues (Selkoe et al., 1988; Weidemann et al., 1989). Unexpectedly, a high amount of $\beta \mathrm{APP}$ expression was detected in astrocytes (compare lane 4 with lanes 2 and 3 ). Astrocytes contained amounts of immunoreactive $\beta$ APP comparable to the transfected 293 cells, whereas microglial cell extracts showed slightly lower amounts of $\beta$ APP (lane 5). For a more detailed analysis, the cell extracts were separated on a $7.5 \%$ gel (Fig. $1 b$ ). As judged by comigration with the $\beta$ APP of the two transfected cell lines, astrocytes and microglial cells contain all major $\beta$ APP isoforms. Band 6 and band 4 (Fig. $1 b$, lanes 4 and 5 ) represent $N^{\prime}$ - and $N^{\prime}$ plus $O^{\prime}-$ glycosylated $\beta \mathrm{APP}_{695}$ (compare to lane 2), whereas band 5 and band 1 indicate the $\mathrm{N}^{\prime}$ - and $\mathrm{N}^{\prime}$ plus $\mathrm{O}^{\prime}$-glycosylated forms of $\beta A P_{751}$ (compare to lanes 1 and 3). Bands 2 and 3 are of unidentified origin but most likely represent posttranslationally modified or slightly degraded forms of $\beta$ APP. Although $\beta A P P_{770}$ is not directly resolved on immunoblots, its presence was confirmed by PCR analysis of mRNA derived from microglia and astrocytes (discussed below). In addition to full-length $\beta \Lambda P P$, we also detected the $\sim 10 \mathrm{kDa}$ fragment (see below) that has previously been shown to remain in the cell membrane after the precursor is constitutively cleaved to produce soluble $\beta$ APP (Selkoe et al., 1988; Esch et al., 1990).

\section{Microglia and astrocytes synthesize $\beta A P P$}

Since it is not clear whether microglial cells and astrocytes synthesize $\beta$ APP or whether its immunochemical detection in those cells is due to uptake of $\beta$ APP, we metabolically labeled the primary tissue culture cells with $\mathrm{L}^{-35} \mathrm{~S}$-methionine and immunoprecipitated $\beta$ APP with $\alpha \mathrm{C} 7$. Figure 2 shows that microglial cells and astrocytes synthesize $\beta$ APP from endogenous mRNA, since we obtained strong signals of labeled $\beta$ APP after immunoprecipitation, comparable to those obtained from the $\beta$ APPtransfected kidney 293 cells. To prove the specificity of our immunoprecipitations, $\alpha \mathrm{C} 7$ was preabsorbed with its corresponding peptide; the reactivity with $\beta$ APP in each cell type was completely abolished (Fig. 2). The high molecular weight bands seen above $\beta$ APP in the microglia and astrocyte lanes may represent coimmunoprecipitating proteins that are bound to $\beta$ APP. They are not detected in transfected kidney cells (Fig. 2), neurons, and PC1 2 cells (data not shown). Their presence in the immunoprecipitates is not due to a cross-reactivity with the antibody $\alpha \mathrm{C} 7$, since we cannot detect the same bands by direct immunoblotting (compare Fig. 2 to Fig. $1 a$ and $b$ ).

By comigration with the transfected cells, we again observed that microglia and astrocytes synthesize at least $\beta \mathrm{APP}_{695}$ and $\beta \mathrm{APP}_{751}$ (Fig. 2). They also contain a small amount of the $\sim 10$ $\mathrm{kDa}$ fragment that is derived from proteolytic processing of $\beta$ APP (arrow in Fig. 2). From these data, we conclude that $\beta$ APP 
a

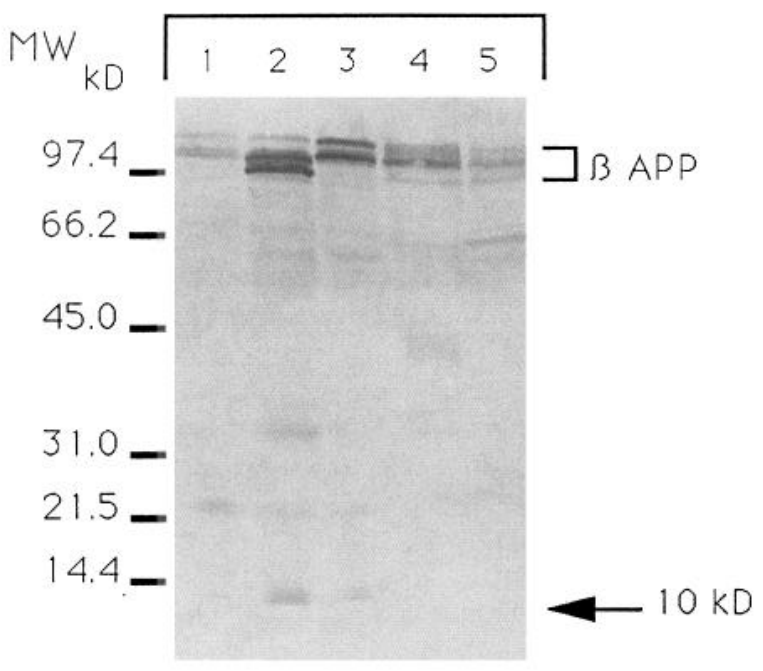

b

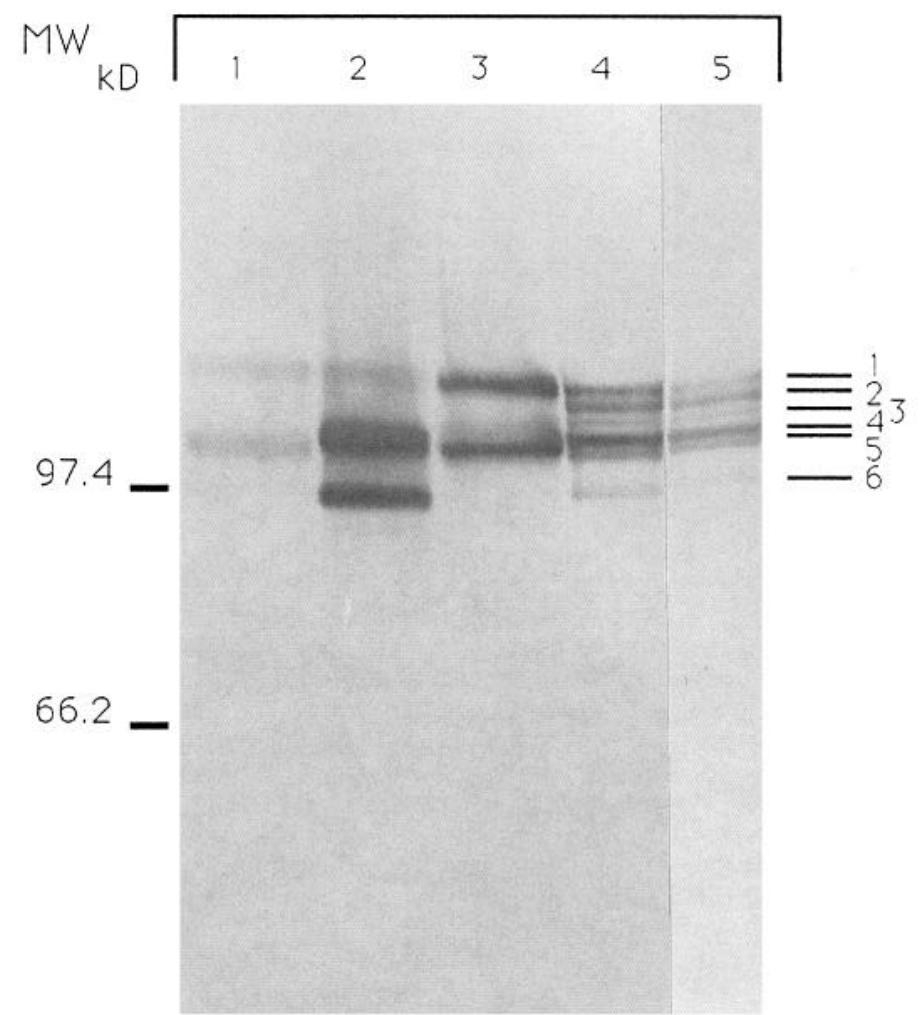

Figure 1. a, Immunoblots of whole-cell extracts separated on a $10 \%$ acrylamide gel. Identical amounts of proteins were loaded in the different lanes. Lane 1, untransfected kidney 293 cells; lane 2, 293 cells stably transfected with $\beta \mathrm{APP}_{695}$; lane 3,293 cells stably transfected with $\beta \mathrm{APP}_{751}$; lane 4, astrocytes; lane 5, microglia. Note that the untransfected kidney 293 cells endogenously express low amounts of $\beta A P P_{751}$. The lack of detection of the $10 \mathrm{kDa} C$-terminal $\beta$ APP fragment in lanes 4 and 5 is due to the relatively low amount of this peptide in astrocytes and microglia (see Fig. 2). For immunoblotting, antibody $\alpha \mathrm{C} 7$ was used in a dilution of $1: 1000 . M W$, molecular weight markers (Bio-Rad). $b$, Immunoblots of whole-cell extracts separated on a $7.5 \%$ acrylamide gel using antibody $\alpha \mathrm{C} 7$. Lanes $1-5$, see Figure 1 a. Numbers on the right represent the different forms of full-length $\beta$ APP discussed in the text.

detection in these cells is due to endogenous synthesis of $\beta$ APP and not to its uptake by endocytosis.

To confirm that rat astrocytes and microglial cells indeed synthesize all three major forms of $\beta$ APP rather than only $\beta \mathrm{APP}_{695}$ (Berkenbosch et al., 1990), we searched for mRNAs coding for the KPI-containing $\beta$ APP forms. For this purpose, we used primers upstream and downstream of the human/rat KPI domain (see Materials and Methods) to amplify mRNAs coding for all three major $\beta$ APP isoforms. From the sequence published for rat $\beta$ APP (Shivers et al., 1988), we expected to obtain amplified cDNAs of 273 and $330 \mathrm{bp}$ from mRNA coding for $\beta \mathrm{APP}_{751}$ and $\beta A P P_{770}$, respectively, and a small cDNA of $105 \mathrm{bp}$ for $\beta A \mathrm{AP}_{695}$. The results are shown in Figure 3. As a control, we again used the transfected and untransfected kidney 293 cells. From microglial cells and astrocytes, we obtained three PCRamplified products of the expected length for $\beta \mathrm{APP}_{695}, \beta \mathrm{APP}_{751}$, and $\beta A P P_{770}$. All three mRNAs are present in rather similar amounts. To confirm further that these cDNAs are derived from $\beta A P P$ mRNAs, they were subcloned into Bluescript vectors and sequenced (data not shown). Sequence analysis revealed that all three cDNAs are identical with the corresponding regions of the three $\beta$ APP isoforms. These data clearly confirm that astrocytes and microglial cells synthesize all three major $\beta$ APP isoforms.

\section{Detection of soluble $\beta A P P$ in microglia and astrocytes}

In addition to full-length $\beta \mathrm{APP}, \alpha \mathrm{C} 7$ immunoprecipitated the $\sim 10 \mathrm{kDa}$ fragment shown in Figure 2. Relative to levels in the transfected kidney 293 cells, both astrocytes and microglia produce much less $10 \mathrm{kDa}$ peptide (Fig. 2). Moreover, the two transfected lines contain different amounts of this fragment. Interestingly, we have consistently observed a higher production of the $10 \mathrm{kDa}$ and other C-terminal-containing proteolytic fragments (M. B. Podlisny and D. J. Selkoe, unpublished observation) in the $\beta \mathrm{APP}_{695}$ transfectants compared to $\beta \mathrm{APP}_{751}$ transfectants (see Fig. 2). To quantify the observed differences in the amount of the $10 \mathrm{kDa}$ fragment among the cells being studied, we analyzed the $\alpha \mathrm{C} 7$ immunoprecipitates by densitometry. For a better comparison, we also added immunoprecipitates from extracts of primary hippocampal neurons cultured from 18-dold rat embryos. For quantification, we compared the amount of all full-length $\beta$ APP bands, regardless of glycosylation state, with the amount of the $10 \mathrm{kDa}$ band. This was necessary because the immature $\mathrm{N}^{\prime}$-glycosylated forms could not be resolved from the mature $\mathrm{N}^{\prime}$ - and $\mathrm{O}^{\prime}$-glycosylated forms while preserving the $10 \mathrm{kDa}$ fragment within the same lane. As a result, the quantitation (Fig. 4) reflects a relative, rather than absolute, ratio of 


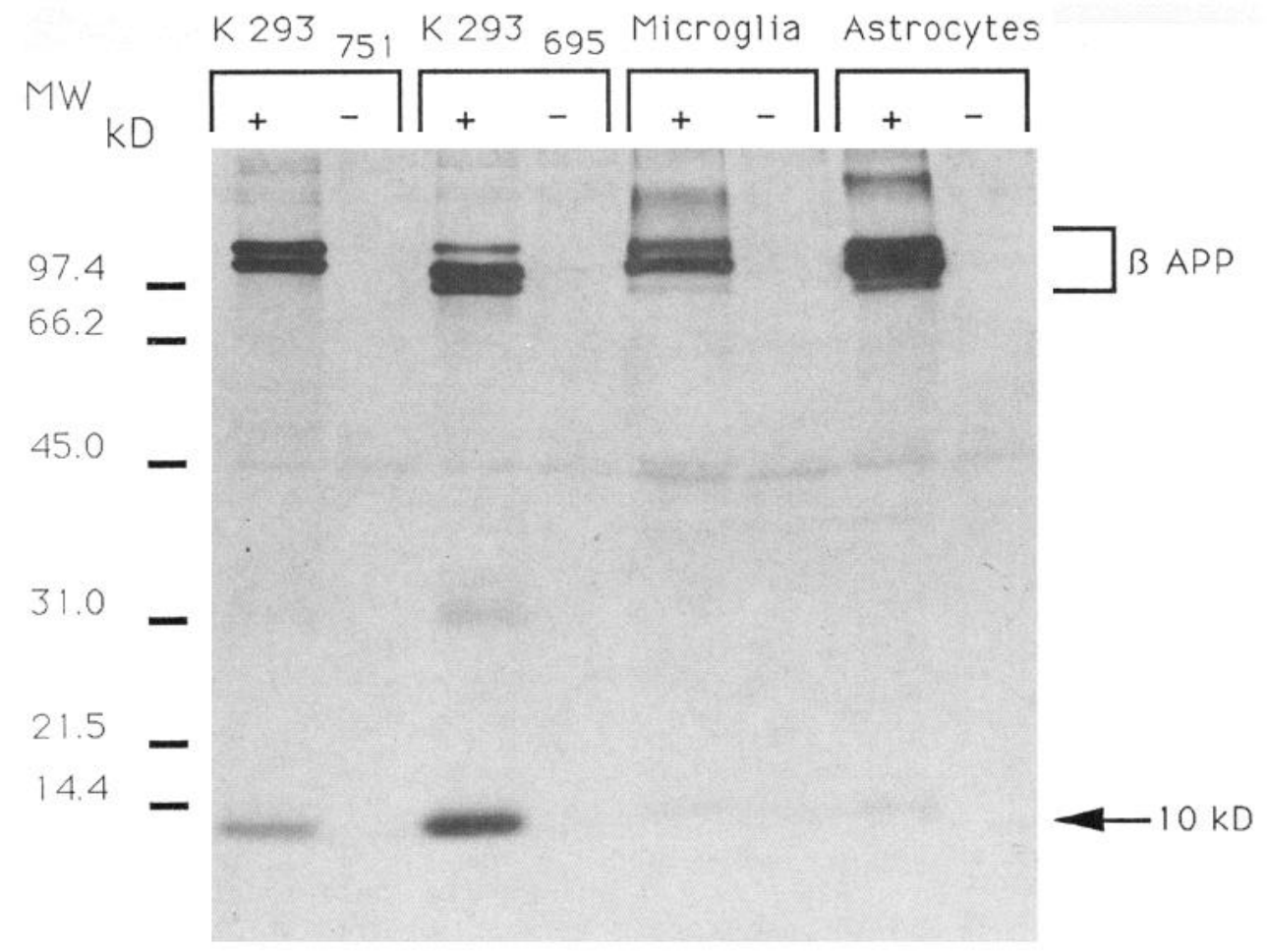

Figure 2. Immunoprecipitation of $\beta$ APP from $\mathrm{L}^{-35} \mathrm{~S}$-methionine-labeled cells using antibody $\alpha \mathrm{C} 7$ at a dilution of $1: 100$. + , without preabsorption of antibody $\alpha \mathrm{C} 7$; - , with preabsorption of antibody $\alpha \mathrm{C} 7$ with its corresponding peptide. In lane $K 293_{695}$, the low endogenous expression of $\beta A P_{751}$ is detected in addition to the expression of $\beta \mathrm{APP}_{695}$ derived from the transfected cDNA. Immunoprecipitations were performed from a total cell number of about $3 \times 10^{6}$ cells per lane. The autoradiogram was exposed overnight. See text for description of bands. the $10 \mathrm{kDa}$ fragment to full-length $\beta \mathrm{APP}$. The comparison shows clearly that the transfected cells contain much higher amounts of the $10 \mathrm{kDa}$ fragment than the other cell types analyzed. In addition, $\beta \mathrm{APP}_{695}$ transfected cells show almost twice as much of the $10 \mathrm{kDa}$ fragment as $\beta \mathrm{APP}_{751}$ transfected cells. The other cell types contain rather small amounts of the $10 \mathrm{kDa}$ fragment. Interestingly, the amount of production of the $10 \mathrm{kDa}$ fragment is not solely dependent on the major $\beta$ APP isoform being expressed by the analyzed cell type. For example, the result with the transfected cells could indicate that $\beta \mathrm{APP}_{695}$ transfectants produce higher amounts of the $10 \mathrm{kDa}$ fragment because that $\beta$ APP isoform lacks the protease inhibitor domain. On the other hand, in neurons, which also express primarily $\beta \mathrm{APP}_{695}$ (data not shown), we detected only very small amounts of the $10 \mathrm{kDa}$ fragment.
The differences in the relative amounts of the $10 \mathrm{kDa}$ fragment in astrocytes and microglia versus the kidney cells could be due to reduced production and secretion of soluble $\beta$ APP or to enhanced turnover of the $10 \mathrm{kDa}$ fragment in the glial cells. To distinguish between these possibilities, we first examined the production of soluble $\beta$ APP forms by immunoprecipitating soluble $\beta$ APP from the conditioned media of metabolically labeled cells with antibody $\alpha \mathrm{R} 1285$, which is directed against residues $527-540$ of $\beta$ APP. Using the same amount of astrocytes and microglial cells as in the experiment described in Figure 2, we were unable to immunoprecipitate soluble $\beta$ APP from tissue culture supernatants, whereas we precipitated large amounts of the soluble form from the transfected 293 cell media (Fig. 5, lanes 2,3$)$. When three times as many glial cells were used, very small amounts of soluble $\beta \mathrm{APP}$, derived from both $\beta \mathrm{APP}_{695}$ and

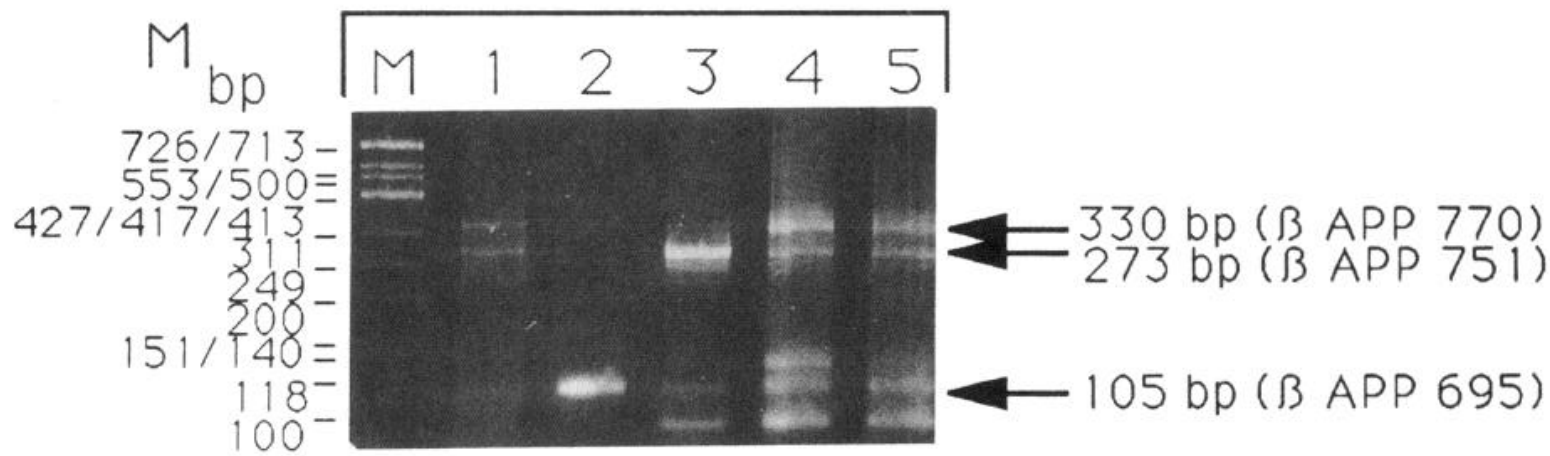

Figure 3. PCR-mediated amplification of $\beta$ APP mRNAs. Ethidium bromide-stained $3 \%$ NuSieve, $1 \%$ agarose gel of PCR products from $1 \mu \mathrm{g}$ of total RNA. Lane 1, untransfected kidney 293 cells; lane 2, 293 cells stably transfected with $\beta$ APP ${ }_{695}$; lane 3,293 cells stably transfected with $\beta \mathrm{APP}_{751}$; lane 4 , astrocytes; lane 5 , microglial cells. The $95 \mathrm{bp}$ and $118 \mathrm{bp}$ PCR products are derived from nonspecific primer aggregates (as determined by sequence analysis). $M$, molecular size markers: $\phi$ X174 DNA cut with HinfI. 


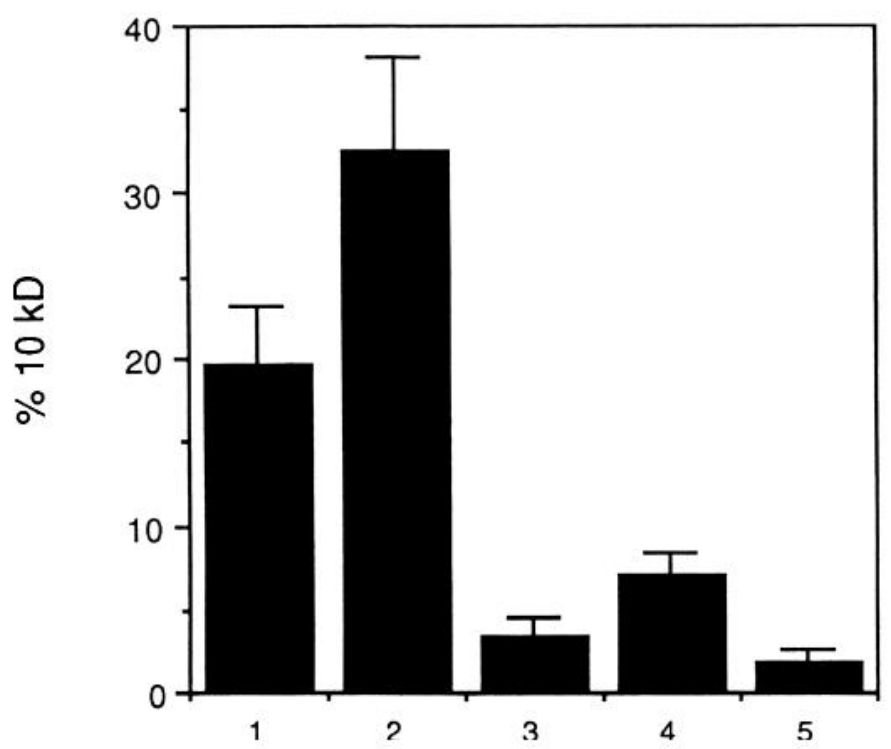

Figure 4. Densitometric analysis of the amount of production of the $10 \mathrm{kDa} \beta$ APP fragment versus full-length $\beta$ APP in immunoprecipitates of several cell types separated on $10 \%$ acrylamide gels. The integrated area of the densitomeric peak representing all full-length $\beta$ APP bands was used as the denominator, and the area of the band in the same lane representing the $10 \mathrm{kDa}$ fragment was used as the numerator. Total cell extracts were immunoprecipitated with antibody $\alpha$ C7. Bar 1, 293 cells transfected with $\beta \mathrm{APP}_{751} ;$ bar 2,293 cells transfected with $\beta \mathrm{APP}_{695} ;$ bar 3, astrocytes; bar 4, microglia; bar 5, primary rat E18 hippocampal neurons. Bars 1,4 , and 5 each represent the mean values $( \pm$ SEM) of three independent experiments; bars 2 and 3, the means of four independent experiments.

$\beta \mathrm{APP}_{751}$, could be immunoprecipitated (Fig. 5, lanes 4, 5). Despite a slightly higher production of the $\sim 10 \mathrm{kDa}$ fragment in microglia (see Fig. 4), we obtained a weaker signal for the soluble forms in conditioned media from microglia than from astrocytes. This may be due to the lower overall synthesis of $\beta$ APP in microglial cells (see Fig. 2). Our data suggest that astrocytes and microglia produce reduced amounts of the soluble $\beta$ APP forms, despite a high level of synthesis of the precursor molecule. Nevertheless, it is still conceivable that this is due only to slower processing through the constitutive secretory pathway. If $\beta$ APP is indeed processed solely by the secretory pathway in glial cells, full-length forms should be turned over more slowly.

To rule out this possibility, pulse-chase experiments were performed on cultured astrocytes. Figure 6 shows that the estimated half-life of full-length $\beta$ APP is about $30-45 \mathrm{~min}$. The short half-life is consistent with data presented by Weidemann et al. (1989) and Oltersdorf et al. (1990), who determined the half-life of $\beta$ APP in cells that produce high amounts of soluble $\beta A P P$. Furthermore, the $10 \mathrm{kDa}$ fragment in the astrocytes is stable over a $4 \mathrm{hr}$ chase period (Fig. 6). These data show that, while astrocytes do not produce significant amounts of the soluble and $10 \mathrm{kDa}$ forms, they turn over full-length $\beta \mathrm{APP}$ at rates comparable to other cells, thereby suggesting the existence of alternative processing pathways.

In addition to the two soluble $\beta$ APP derivatives, we also obtained a $31 \mathrm{kDa}$ fragment in immunoprecipitates from the conditioned media of microglial cells using antibody $\alpha \mathrm{R} 1285$ (Fig. 5, arrow). This fragment, which is currently being further characterized, has not been detected in all other cell types so far analyzed.

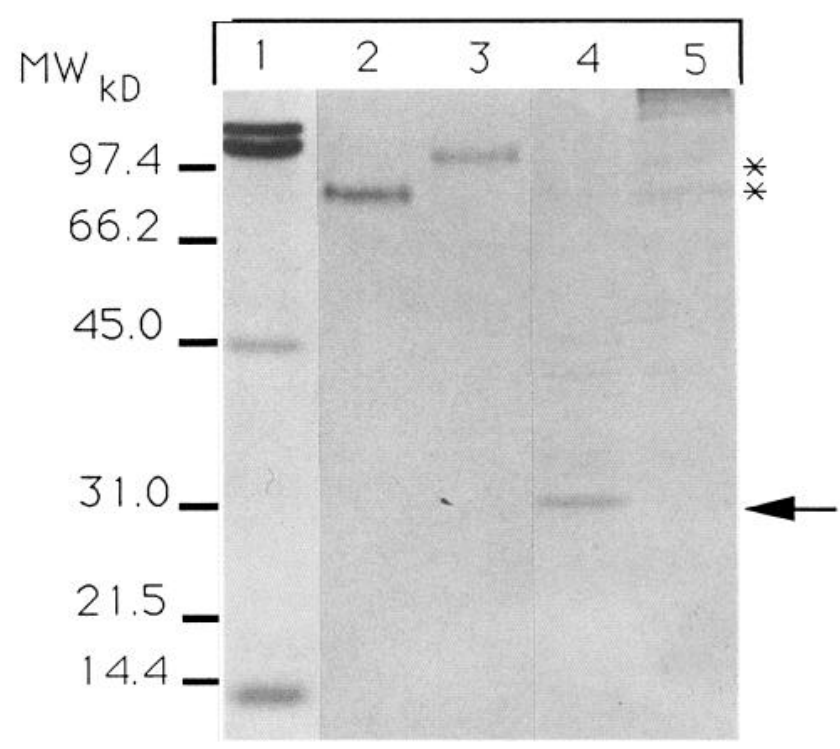

Figure 5. Immunoprecipitation of soluble $\beta$ APP from the medium of

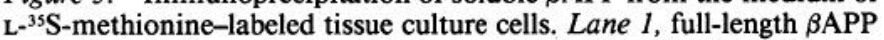
precipitated with antibody $\alpha \mathrm{C} 7$ from cell extracts of kidney 293 cells transfected with $\beta \mathrm{APP}_{751}$ as described in Figure $2\left(\mathrm{~K}_{293_{751}}\right)$. Lanes 2 5 , supernatants of $\mathrm{L}^{-35} \mathrm{~S}$-methionine-labeled cells immunoprecipitated with antibody $\alpha \mathrm{R} 1285$ (dilution, 1:100). Lane 2, supernatant of 293 cells stably transfected with $\beta \mathrm{APP}_{695}$; lane 3 , supernatant of 293 cells stably transfected with $\beta \mathrm{APP}_{751}$; lane 4 , supernatant of microglial cells; lane 5, supernatant of astrocytes. Asterisks indicate the two soluble derivatives of $\beta \mathrm{APP}$, which are faintly present in lanes 4 and 5 . For immunoprecipitation of soluble $\beta$ APP forms from kidney 293 cells, the conditioned medium of $\sim 6 \times 10^{6}$ cells was used. Note that the immunoprecipitations from microglial and astrocyte culture media was performed using $\sim 1.8 \times 10^{7}$ cells. Arrow indicates a $31 \mathrm{kDa}$ fragment specifically immunoprecipitated by R 1285 in medium from microglial cells. Exposure time, 1 week.

\section{Immunocytochemical detection of $\beta A P P$ in microglial cells and astrocytes}

We examined the subcellular localization of $\beta$ APP in cultured cells by indirect immunofluorescence. Using affinity-purified antibody $\alpha \mathrm{C} 7$ (to $\beta$ APP residues 676-695) on primary rat microglia, we observed a punctate, perinuclear staining pattern suggestive of Golgi membranes (Fig. 7a-c). Furthermore, some cytoplasmic vesicles stained intensely for $\beta$ APP. Antibody $\alpha \mathrm{R} 1285$ gave an identical pattern (data not shown). A monoclonal antibody (OX42) against the rat macrophage surface antigen CR3 recognized epitopes with a similar intracellular distribution. In contrast to $\beta$ APP antibodies, however, OX42 showed definite immunoreaction at the cell surface (Fig. $7 a^{\prime}-$ $\left.c^{\prime}\right)$. In view of the previous characterization of $\beta$ APP as a transmembrane glycoprotein (Kang et al., 1987), its limited presence on cell surface membranes is somewhat unexpected. Astrocyte staining similarly revealed a granular distribution of $\beta$ APP centered around the nucleus and again showed nearly no cell surface staining (Fig. 8a). This vesicular pattern differs strikingly from the cytoskeletal pattern of an antibody against GFAP (Fig. $8 b$ ) that was used to confirm the identity of astrocyte cultures. The pattern of immunoreactivity with antibodies against $\beta$ APP in these cell types is similar to that found in the transfected 293 cells (Selkoe et al., 1988).

To confirm the apparent lack of cell surface staining, we performed double labeling of cultured microglia in which cell surface proteins are labeled on living, unfixed cells (Bakke and 


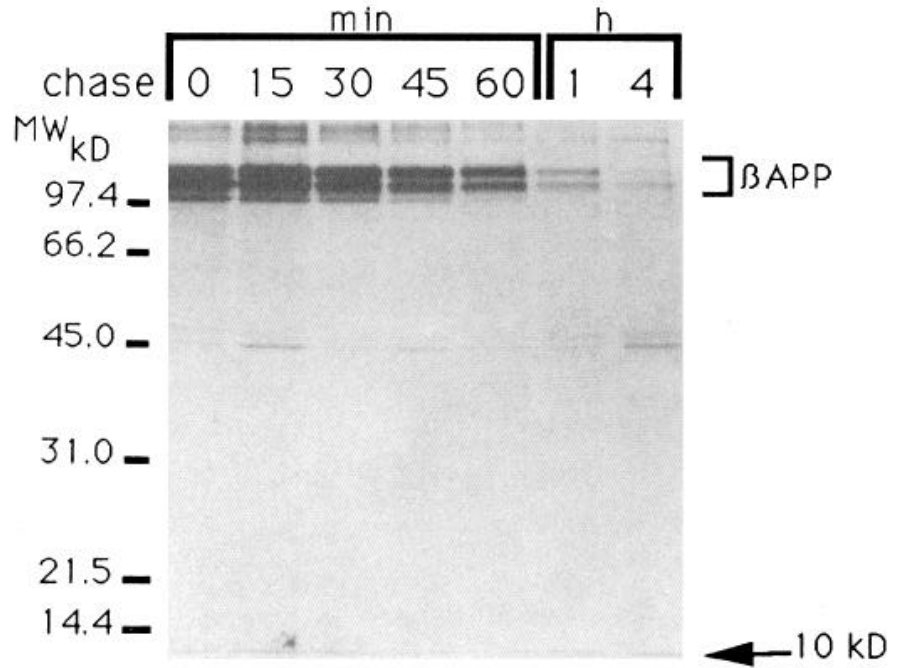

Figure 6. A pulse-chase experiment using primary astrocytes. Cells were pulse labeled for $20 \mathrm{~min}$ and chased in medium containing excess amounts of unlabeled $\beta$ APP for the indicated time periods. Immunoprecipitations were performed using antibody $\alpha \mathrm{C} 7$. While the $10 \mathrm{kDa}$ fragment (arrow) is present in very small amounts, it is still stable after a $4 \mathrm{hr}$ chase period. The half-life of full-length $\beta$ APP is about $30-45$ min. Since astrocytes express all three major forms of $\beta$ APP, it is not possible to analyze the process of glycosylation in detail. The autoradiogram was exposed for $6 \mathrm{~d}$.

Dobberstein, 1990). Using the monoclonal antibody 22C11, which recognizes the extreme N-terminus of $\beta$ APP (following the signal peptide), to label living cells, we observed a very low amount of cell surface staining, whereas $\alpha \mathrm{C} 7$ produced strong intracellular staining within the same cells after permeabilization with $0.1 \%$ Triton X-100 (compare Fig. 9, $a$ and $b$, with Fig. $9, a^{\prime}$ and $b^{\prime}$ ). If $22 \mathrm{C} 11$ was applied after Triton permeabilization, it similarly demonstrated the presence of abundant intracellular $\beta \mathrm{APP}$ (data not shown). In contrast, the control antibody OX42, raised against a cell surface protein, revealed strong cell surface labeling prior to cell permeabilization; after Triton treatment, intracellular vesicular staining was also seen (Fig. $9 c, d$ ). Similar results were obtained with astrocytes (data not shown). While a lack of cell surface staining would not be unexpected in cells that secrete large amounts of soluble $\beta \mathrm{APP}$, it is surprising that full-length forms in glial cells that are not cleaved also do not arrive at the cell surface. These data, together with the reduced production of the $10 \mathrm{kDa}$ fragment (Fig. 4) and the soluble derivatives of $\beta$ APP (Fig. 5), indicate that $\beta$ APP mediates its biological function in these cells only to a minor extent as a surface protein.

\section{Discussion}

Among mammalian tissues examined to date, brain has been found to have the highest level of expression of $\beta$ APP. Although neuronal transcription of $\beta$ APP has been extensively studied by in situ hybridization of brain sections and biochemical analysis of cultured neuronal-like cells (see, e.g., Bahmanyar et al., 1987; Goedert, 1987; Cohen et al., 1988; Higgins et al., 1988; Schubert et al., 1989b; Johnson et al., 1990), there is limited information about astrocytic $\beta$ APP expression, and the presence of $\beta$ APP in microglia has not been reported. Both astrocytes and microglia are prominent constituents of the $\mathrm{A} \beta \mathrm{P}$-rich neuritic plaques that occur abundantly in Alzheimer's disease and trisomy 21 and,
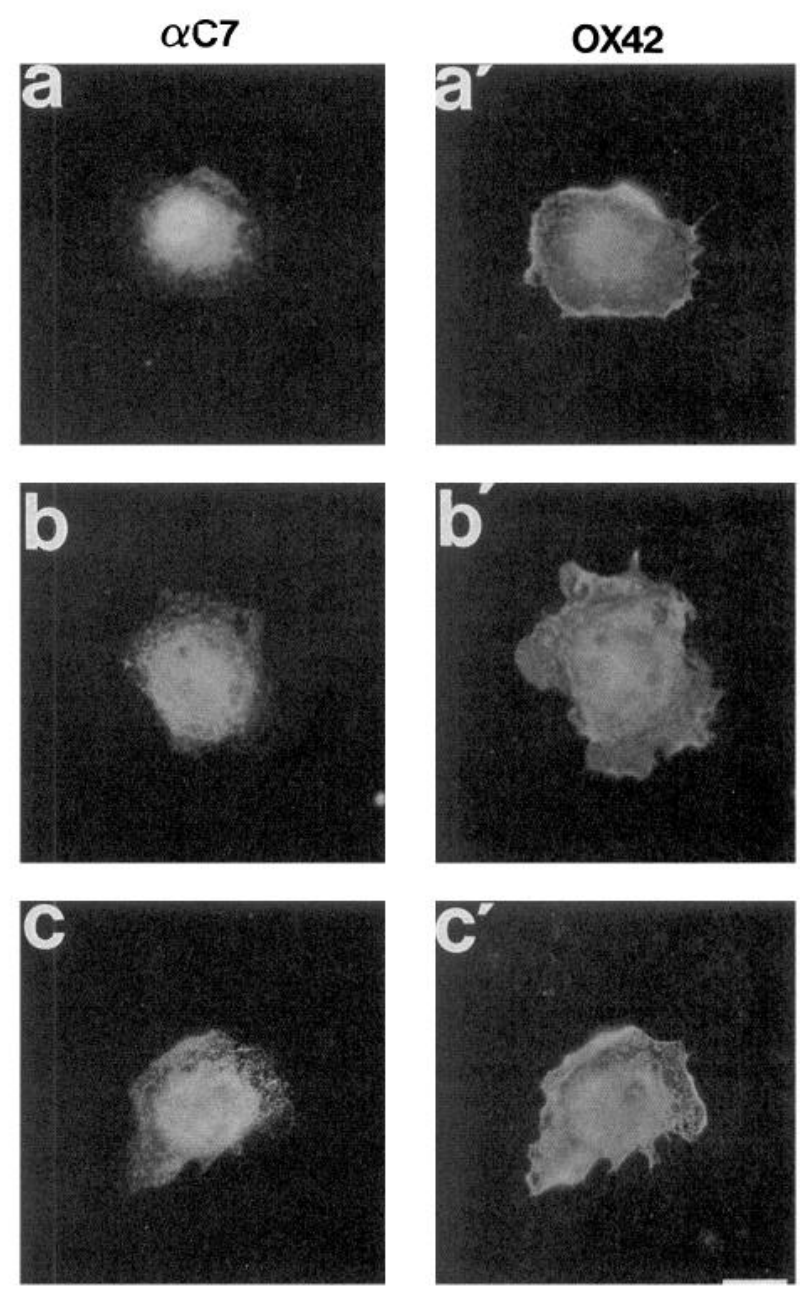

Figure 7. Immunocytochemical analysis of $\beta$ APP expression in microglial cells from primary cultures of rat cortex. Cells were fixed with methanol/acetone (see Materials and Methods) and then double labeled with a polyclonal antibody against $\beta \mathrm{APP}(\alpha \mathrm{CT})$ and a monoclonal antibody (OX42) against the macrophage surface antigen CR3. The polyclonal antibody was identified with TRITC-conjugated goat anti-rabbit $\mathrm{IgG}$, and the monoclonal antibody, with FITC-conjugated goat antimouse IgG. $a-c$, Three examples of microglial cells demonstrating expression of $\beta \mathrm{APP}$ using affinity-purified antibody $\alpha \mathrm{C} 7$. Note the granular vesicular staining concentrated in the perinuclear cytoplasm. $a^{\prime}-c^{\prime}$, Same cells as in $a-c$, stained with mAb OX42, thus confirming their identity as microglial cells. Note the prominent cell surface localization in addition to the punctate intracellular staining seen with OX42. Scale bar, $10 \mu \mathrm{m}$.

to a lesser extent, during normal brain aging. Here, we characterize the expression of $\beta$ APP in primary cultures of cortical microglia and astrocytes. We show that both cell types synthesize substantial amounts of $\beta$ APP. However, in comparison to published studies of cDNA-transfected cells (Weidemann et al., 1989; Oltersdorf et al., 1990), microglia and astrocytes show markedly reduced processing of full-length $\beta$ APP into soluble, secreted forms. As shown by pulse labeling of astrocytes, this is not merely due to a slower cleavage rate of the precursor molecule, since full-length $\beta$ APP is still rapidly turned over (with a half-life of about $30-45 \mathrm{~min}$ ) in astrocytes. In these cells, $\beta$ APP is localized in intracellular vesicles and displays very little insertion at the cell surface. Our findings lead to the hypothesis that $\beta$ APP, at least in CNS glial cells, may have an intracellular 

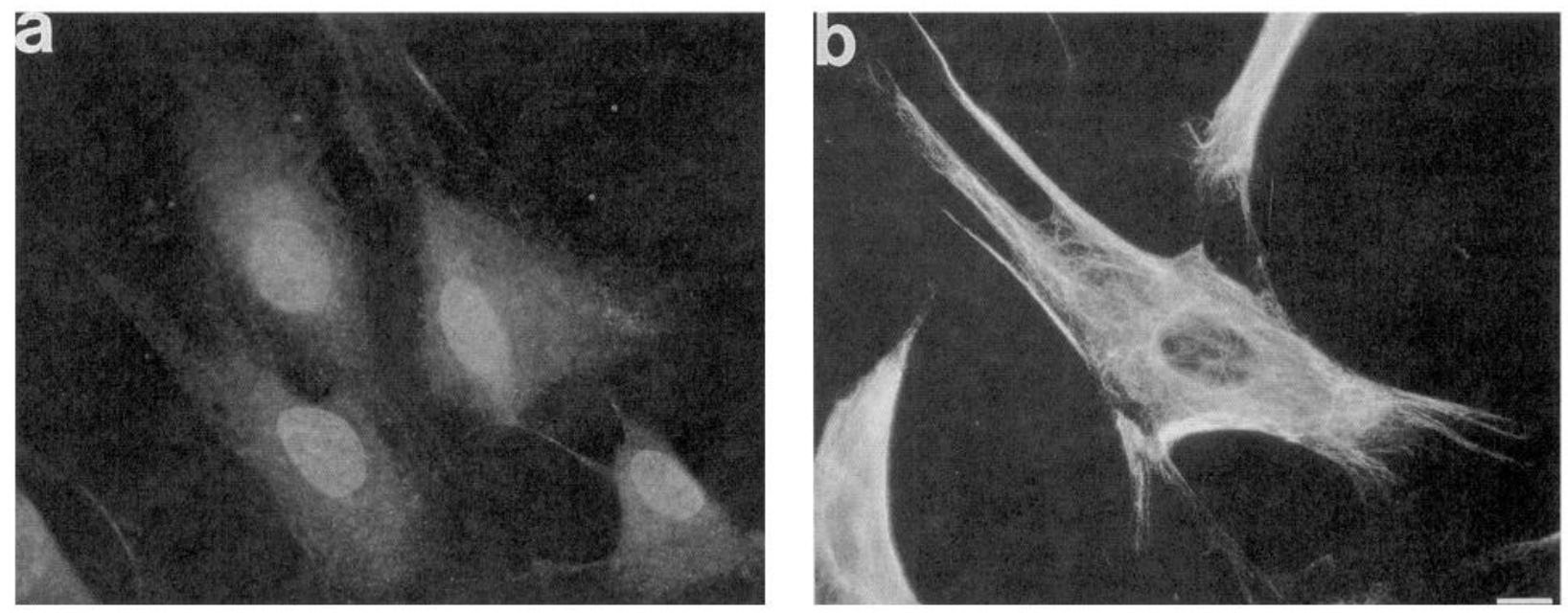

Figure 8. Immunocytochemical analysis of $\beta$ APP expression in primary cultured rat astrocytes. Cells were fixed in methanol/acetone (see Materials and Methods) and then single labeled with polyclonal antibodies against either $\beta$ APP or GFAP. TRITC-conjugated goat anti-rabbit IgG was used to visualize labeled epitopes. $a$, Cultured astrocytes stained with affinity-purified $\alpha \mathrm{C} 7$ against $\beta$ APP. Note the prominent cytoplasmic granular staining pattern, especially around and overlying the cell nucleus. $b$, Astrocytes stained with a polyclonal antibody against GFAP, thus confirming their cellular identity. Scale bar, $10 \mu \mathrm{m}$.

function rather than serving principally as a precursor for soluble $\beta$ APP derivatives that act extracellularly.

The small amounts of soluble, carboxyl-truncated $\beta$ APP we detected in the conditioned media of astrocytes and microglia were reflected in the low levels of the constitutive $\sim 10 \mathrm{kDa}$ carboxyl-terminal fragment found in cell lysates. As shown in Figure 4, densitometric quantitation of the ratio of $10 \mathrm{kDa}$ to full-length $\beta$ APP forms provides a simple and rapid method for comparing the extent of $\beta$ APP processing through the constitutive proteolytic pathway in primary cultured cells or permanent cell lines. Among the three major CNS cell types we have analyzed, all show much less constitutive processing of $\beta$ APP into secreted forms than do the transfected cells that have been used to characterize the metabolic fate of $\beta$ APP heretofore (Weidemann et al., 1989; Esch et al., 1990; Oltersdorf et al., 1990). Interestingly, the lowest level of $10 \mathrm{kDa}$ production we observed occurred in neurons (Fig. 4). If our results in primary cultures of cortical cells reflect the situation in brain, then neurons, astrocytes, and microglia may process only a minority of fulllength $\beta$ APP molecules through the constitutive secretory pathway, leaving most molecules inserted into membranes. Our immunocytochemical results demonstrate very little insertion of the precursor at the cell surface and abundant $\beta$ APP in membranous organelles in the cytoplasm. Taken together, these findings lead to the hypothesis that a significant portion of $\beta$ APP in glial cells may remain in the endoplasmic reticulum, Golgi complex, or other internal vesicular components and thus may serve primarily an intracellular function.

In addition to the implications of this hypothesis for models of $\beta$ APP as a cell surface receptor (Kang et al., 1987; Weidemann et al., 1989) or principally as a precursor for PN-II secretion (Oltersdorf et al., 1989; Van Nostrand et al., 1989), it has implications for current ideas about the alteration of normal $\beta$ APP processing in Alzheimer's disease. The finding by Esch et al. (1990) that constitutive secretion of PN-II involves a proteolytic cleavage at residue 16 within the $A \beta P$ region (residue 612 of $\beta \mathrm{APP}_{695}$ ) has led to the concept that the currently unidentified enzyme responsible for this clip (referred to as APP secretase) normally prevents generation of $\beta$-amyloid and thus may be reduced in activity or otherwise inefficient in some cells in Alzheimer's disease. It could be further speculated that pharmacologically increasing the activity of APP secretase might enhance the constitutive cleavage of $\beta$ APP and decrease the genesis of $\mathrm{A} \beta \mathrm{P}$. However, the results reported here suggest that many $\beta$ APP molecules in neurons and glia may not be destined for processing by this pathway, and therefore the identification and subsequent modulation of APP secretase may not turn out to be an advantageous therapeutic target in Alzheimer's disease. Instead, many $\beta$ APP molecules may function physiologically as full-length, membrane-bound polypeptides and then be catabolized through a normal pathway that involves generation of fragments that contain intact $\mathrm{A} \beta \mathrm{P}$ and perhaps limited production of $\mathrm{A} \beta \mathrm{P}$ itself. For example, our detection of a soluble 31 $\mathrm{kDa}$ protein with an antibody to $\beta$ APP residues $527-540$ (and preliminarily with $\alpha \mathrm{C} 7$ ) in the media of microglia raises the possibility that this is a catabolic fragment of the precursor protein that contains the $\mathrm{A} \beta \mathrm{P}$ region and is potentially amyloidogenic. The proteases responsible for the sequential degradative cleavages of $\beta$ APP, particularly those clipping at the $\mathrm{N}$ and $\mathrm{C}$-termini of $\mathrm{A} \beta \mathrm{P}$, remain potentially attractive targets for therapeutic intervention.

Another implication of our findings is that the extent to which full-length $\beta$ APP is constitutively processed to release PN-II varies considerably among different cells. For example, it is known that platelets stimulated with calcium ionophores or thrombin secrete large amounts of this C-truncated form (Bush et al., 1990; Cole et al., 1990; Smith et al., 1990; Van Nostrand et al., 1990), which can then function as a soluble protease inhibitor. In addition, while platelets contain only small amounts of full-length $\beta$ APP, they contain large amounts of both PN-II and the $10 \mathrm{kDa}$ fragment (M. Schlossmacher and D. J. Selkoe, unpublished observations). This is consistent with our prediction that the ratio of the $10 \mathrm{kDa}$ C-terminal fragment to fulllength $\beta$ APP forms is a useful monitor for measuring the degree of cleavage into PN-II. Our findings suggest that processing of $\beta \mathrm{APP}$ into soluble PN-II may be a function of both the cell type 
and the predominant isoforms of $\beta$ APP being transcribed. In the kidney 293 cell line, $\beta \mathrm{APP}_{695}$-transfected cells produce almost twice as much of the $10 \mathrm{kDa}$ fragment as $\beta \mathrm{APP}_{751}$-transfected sister cells grown simultaneously under identical conditions (Figs. 2, 4). Since the only difference between these two populations of cells is the presence of the Kunitz protease inhibitor domain in the latter, one may assume that this domain is capable of inhibiting proteolysis of the precursor molecule by decreasing the activity of the APP secretase. On the other hand, such a mechanism cannot be responsible for the very low production of the $10 \mathrm{kDa}$ fragment that we observed in primary cultures of fetal neurons, since neurons at this age have been shown to express much more $\beta \mathrm{APP}_{695}$ than $\beta \mathrm{APP}_{751}$ (Neve et al., 1988). We hypothesize that both cell type-specific and isoform-specific differences in the relative usage of various $\beta$ APP processing pathways are likely to exist.

The cells that synthesize those $\beta$ APP molecules that give rise to microvascular and senile plaque amyloid deposits in aged and Alzheimer's disease brain tissue are currently unknown. Several laboratories have demonstrated a very close relationship among microglial cells, astrocytes, and mature amyloid-bearing senile plaques (see, e.g., Haga et al., 1989; Itagaki et al., 1989; Wisniewski et al., 1989; Cras et al., 1990). Microglia are frequently found in the centers of such plaques, within the amyloid deposit, whereas astrocytes are often concentrated around the periphery of a plaque and appear to extend some processes toward the plaque center (Itagaki et al., 1989). Both astrocytes (Siman et al., 1989) and microglia (Wisniewski et al., 1989) have been postulated as the cells of origin of senile plaque amyloid. Indeed, Wisniewski et al. (1989) have examined senile plaques by electron microscopy and described vesicles derived from the Golgi apparatus apparently fusing with so-called amyloid-filled channels in the cytoplasm of microglial cells. This appearance led these investigators to propose that microglial cells do not take up the amyloid fibrils by phagocytosis, as one would expect for a macrophage-like cell, but rather are the cells that make $\beta$-amyloid.

Our data show that microglial cells synthesize all three major isoforms of $\beta$ APP and have a low rate of proteolytic cleavage of the precursors within the $\mathrm{A} \beta \mathrm{P}$ region. However, this does not necessarily implicate these cells as the source of plaque amyloid. Most amorphous or diffuse $\mathrm{A} \beta \mathrm{P}$ plaques, which are believed to represent very early deposits that may serve as a precursor of mature senile plaques, are not specifically associated with microglial cells, as judged by HLA-DR labeling (Itagaki et al., 1989). For example, in Alzheimer's disease cerebellum, where numerous diffuse $\mathrm{A} \beta \mathrm{P}$ plaques occur with very little or no surrounding neuritic alteration, we were unable to demonstrate any spatial association with HLA-DR-positive microglia, whereas this marker readily identified reactive microglia in most mature plaques of the cerebral cortex from the same brain (Joachim et al., 1989c). Similarly, GFAP-positive reactive astrocytes are usually not detectable in diffuse plaques. Since such diffuse $A \beta P$ deposits seem to precede by many years the appearance of mature plaques, neuritic dystrophy, neurofibrillary tangles, and other cortical lesions in Down's syndrome (Giaccone et al., 1989) and, by implication, in Alzheimer's disease, it is unlikely that reactive microglia or astrocytes are the source of the initial deposition of $\mathrm{A} \beta \mathrm{P}$ in these disorders. Nevertheless, our findings that these cell types synthesize large amounts of $\beta \mathrm{APP}$, at least in vitro, suggest that there could be multiple cellular sources for the $\mathrm{A} \beta \mathrm{P}$ deposited within mature amyloid plaques.
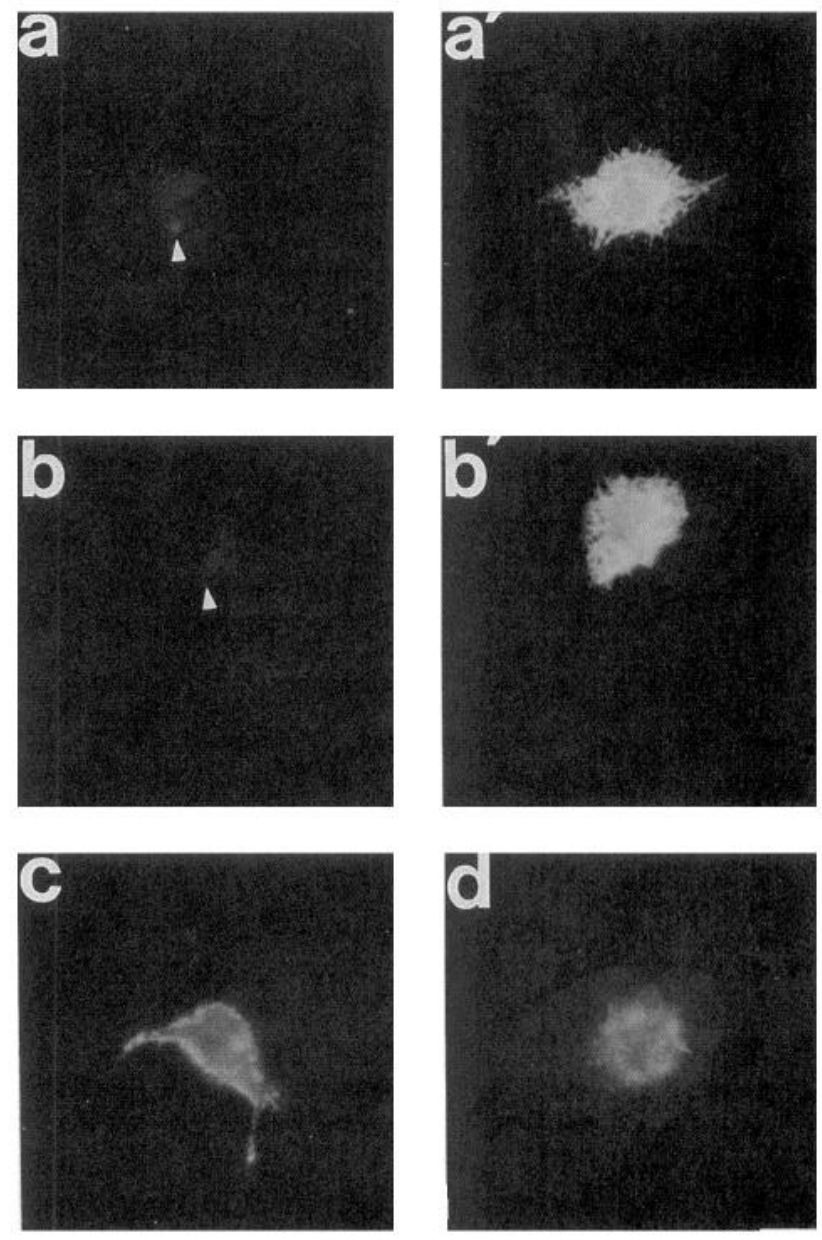

Figure 9. Double-label immunocytochemistry of microglial cells before and after permeabilization with Triton X-100. For cell surface labeling, living cells were incubated on ice with a monoclonal antibody against $\beta$ APP $(22 \mathrm{C} 11)$. These epitopes were visualized with FITC-conjugated goat anti-mouse IgG. Intracellular $\beta$ APP epitopes were then identified by fixing the cells in $4 \%$ paraformaldehyde $/ 0.12 \mathrm{~m}$ sucrose, permeabilizing with $0.1 \%$ Triton X-100, and staining with $\alpha \mathrm{C} 7$ and TRITC-conjugated goat anti-rabbit IgG. $a$ and $b$, Two examples of cell surface labeling with $\mathrm{mAb} 22 \mathrm{C} 11$. Note the nearly complete absence of $\beta$ APP cell surface epitopes (arrowheads indicate position of cells). $a^{\prime}$ and $b^{\prime}$, Same cells as in $a$ and $b$ stained with $\alpha \mathrm{C} 7$ after fixation and permeabilization. Note the prominent intracellular staining. The apparent lack of the granular vesicular pattern that was seen in Figures 7 and $8 a$ is due to the use of Triton for permeabilization. $c$ and $d$, As a control, microglia cell surface and intracellular labeling was performed with mAb OX42. $c$, Surface labeling of a living microglial cell. Note the prominent plasma membrane staining (compare also Fig. $6 a^{\prime}-c^{\prime}$ ). $d$, Intracellular staining of a permeabilized microglial cell. Scale bar, 10 $\mu \mathrm{m}$.

\section{References}

Bahmanyar S, Higgins GA, Goldgaber D, Lewis DA, Morrison JH, Wilson MC, Shankar SK, Gajdusek DC (1987) Localization of amyloid $\beta$ protein messenger RNA in brains from patients with Alzheimer's disease. Science 237:77-80.

Bakke O, Dobberstein B (1990) MHC Class II-associated invariant chain contains a sorting signal for endosomal compartments. Cell 63: 707-716.

Banker GA, Cowan WM (1977) Rat hippocampal neurons in dispersed cell culture. Brain Res 126:397-425.

Bartlett WP, Banker GA (1984) An electron microscopic study of the development of the axons and dendrites by hippocampal neurons in 
culture. I. Cells which develop without intercellular contacts. J Neurosci 4:1944-1953.

Berkenbosch F, Refolo LM, Friedrich VL Jr, Casper D, Blum M, Robakis NK (1990) The Alzheimer's amyloid precursor protein is produced by type I astrocytes in primary cultures of rat neuroglia. J Neurosci Res 25:431-440.

Bottenstein JE, Sato GH (1979) Growth of a rat neuroblastoma cell line in serum-free supplemented medium. Proc Natl Acad Sci USA 76:514-519.

Bush AI, Martins RN, Rumble B, Moir R, Fuller S, Milward E, Currie J, Ames D, Weidemann A, Fischer P, Multhaup G, Beyreuther K, Masters CL (1990) The amyloid precursor protein of Alzheimer's disease is released by human platelets. J Biol Chem 265:1 5977-15983.

Card JP, Meade PR, Davis LG (1988) Immunocytochemical localization of the precursor protein for beta-amyloid in rat central nervous system. Neuron 1:835-846.

Cohen ML, Golde TE, Usiak MF, Younkin LH, Younkin SG (1988) In situ hybridization of nucleus basalis neurons shows increased $\beta$-amyloid mRNA in Alzheimer disease. Proc Natl Acad Sci USA 85: 1227-1231.

Cole GM, Galasko D, Shapiro IP, Saitoh T (1990) Stimulated platelets release amyloid $\beta$-protein precursor. Biochem Biophys Res Commun 170:288-295.

Cras P, Kawai M, Siedlak S, Mulvihill P, Gambetti P, Lowery D, Gonzalez-DeWhitt P, Greenberg B, Perry G (1990) Neuronal and microglial involvement in beta-amyloid protein deposition in Alzheimer's disease. Am J Pathol 137:241-246.

De Sauvage F, Octave J-N (1988) A novel mRNA of the A4 amyloid precursor gene coding for a possibly secreted protein. Science 245: 651-653.

Esch FS, Keim PS, Beattie EC, Blacher RW, Culwell AR, Oltersdorf T, McClure D, Ward PJ (1990) Cleavage of amyloid $\beta$-peptide during constitutive processing of its precursor. Science 248:1122-1124.

Frei K, Siepl C, Groseurth P, Bodmer S, Schwerdel C, Fontana A (1987) Antigen presentation and tumor cytotoxicity by interferon-gammatreated microglial cells. Eur J Immunol 17:1271-1278.

Giaccone G, Tagliavini F, Linoli G, Bouras C, Frigerior L, Frangione B, Bugiani $O$ (1989) Down patients: extracellular preamyloid deposits precede neuritic degeneration and senile plaques. Neurosci Lett 97:232-238.

Giulian D, Baker TJ (1986) Characterization of ameboid microglia isolated from developing mammalian brain. J Neurosci 6:2163-2178.

Glenner GG, Wong CW (1984) Alzheimer's disease: initial report of the purification and characterization of a novel cerebrovascular amyloid protein. Biochem Biophys Res Commun 120:885-890.

Goedert M (1987) Neuronal localization of amyloid beta protein precursor mRNA in normal human brain and in Alzheimer's disease. EMBO J 6:3627-3632.

Golde TG, Estus S, Usiak M, Younkin LH, Younkin SG (1990) Expression of $\beta$ amyloid protein precursor mRNAs: recognition of a novel alternatively spliced form and quantification in Alzheimer's disease using PCR. Neuron 4:253-267.

Goldgaber D, Lerman MI, McBride OW, Saffiotti V, Gajdusek DC (1987) Characterization and chromosomal localization of a cDNA encoding brain amyloid of Alzheimer's disease. Science 235:877-880.

Graeber MB, Banati RB, Streit WJ, Kreutzberg GW (1989) Immunophenotypic characterization of rat brain macrophages in culture. Neurosci Lett 103:241-246.

Haga S, Akai K, Ishii T (1989) Demonstration of microglial cells in and around senile (neuritic) plaques in the Alzheimer brain. An immunohistochemical study using a novel monoclonal antibody. Acta Neuropathol (Berl) 77:569-575.

Higgins GA, Lcwis DA, Bahmanyar S, Goldgaber D, Gajdusck DC, Young WG, Morrison JH, Wilson MC (1988) Differential regulation of amyloid- $\beta$-protein mRNA expression within hippocampal neuronal subpopulations in Alzheimer disease. Proc Natl Acad Sci USA 85:1297-1301.

Ishii T, Kametani F, Haga S, Sato M (1989) The immunohistochemical demonstration of subsequences of the precursor of the amyloid A4 protein in senile plaques in Alzheimer's disease. J Neuropathol Appl Neurobiol 15:135-147.

Itagaki S, McGeer PL, Akiyama H, Zhu S, Selkoe DJ (1989) Relationship of microglia and astrocytes to amyloid plaques of Alzheimer disease. J Neuroimmunol 24:173-182.

Joachim CL, Mori H, Selkoe DJ (1989a) Amyloid $\beta$-protein deposition in tissues other than brain in Alzheimer's disease. Nature 341:226230.

Joachim CL, Morris JH, Platt D, Selkoe DJ (1989b) Diffuse senile plaques: the caudate and putamen as a model. J Neuropathol Exp Neurol 48:330.

Joachim CL, Morris JH, Selkoe DJ (1989c) Diffuse amyloid plaques occur commonly in the cerebellum in Alzheimer's disease. $\Lambda \mathrm{m} \mathrm{J}$ Pathol 5:309-319.

Johnson SA, McNeill T, Cordell B, Finch CE (1990) Relationship of neuronal APP-751/APP-695 mRNA ratio and neuritic plaque density in Alzheimer's disease. Science 248:854-857.

Kang J, Lemaire H-G, Unterbeck A, Salbaum M, Masters CL, Grzeschik KH, Multhaup G, Beyreuther K, Müller-Hill B (1987) The precursor of Alzheimer's disease amyloid A4 protein resembles a cell-surface receptor. Nature 325:733-736.

Kitaguchi N, Takahashi Y, Tokushima Y, Shiojiri S, Ito H (1988) Novel precursor of Alzheimer's disease amyloid protein shows protease inhibitory activity. Nature 331:530-532.

Koo EH, Sisodia SS, Archer DA, Martin LJ, Weidemann A, Beyreuther K, Masters CL, Fischer P, Price DL (1990) Precursor of amyloid protein in Alzheimer's disease undergoes fast anterograde axonal transport. Proc Natl Acad Sci USA 87:1561-1565.

Laemmli UK (1970) Cleavage of structural proteins during the assembly of the head of bacteriophage T4. Nature 227:680-685.

Maniatis T, Fritsch EF, Sambrook J (1989) Molecular cloning: a laboratory manual. Cold Spring Harbor, NY: Cold Spring Harbor Laboratory.

Masters CL, Multhaup G, Simms G, Pottgiesser J, Martins RN, Beyreuther K (1985a) Neuronal origin of a cerebral amyloid: neurofibrillary tangles of Alzheimer's disease contain the same protein as the amyloid of plaque cores and blood vessels. EMBO J 4:2757-2763.

Masters CI, Simms G, Weinman NA, Multhaup G, McDonald BL, Beyreuther K (1985b) Amyloid plaque core protein in Alzheimer disease and Down syndrome. Proc Natl Acad Sci USA 82:4245-4249.

McCarthy KD, de Vellis J (1980) Preparation of separate astroglial and oligodendroglial cell cultures from rat cerebral tissue. J Cell Biol 85:890-892.

Motte J, Williams RS (1989) Age-related changes in the density and morphology of plaques and neurofibrillary tangles in Down syndrome brain. Acta Neuropathol (Berl) 77:535-546.

Neve RL, Finch EA, Dawes LA (1988) Expression of the Alzheimer amyloid precursor gene transcripts in the human brain. Neuron 1: 669-677.

Ohyagi Y, Takahashi K, Kamegai M, Tabira T (1990) Developmental and differential expression of $\beta$ amyloid protein precursor mRNAs in mouse brain. Biochem Biophys Res Commun 167:54-60.

Oltersdorf T, Fritz LC, Schenk DB, Lieberburg I, Johnson-Wood KL, Beattie EC, Ward PJ, Blacher RW, Dovey HF, Sinha S (1989) The secreted form of the Alzheimer's amyloid precursor protcin with the Kunitz domain is protease nexin-II. Nature 341:144-147.

Oltersdorf T, Ward PJ, Henriksson T, Beattie EC, Neve R, Lieberburg I, Fritz LC (1990) The Alzheimer amyloid precursor protein. Identification of a stable intermediate in the biosynthetic/degradative pathway. J Biol Chem 265:4492-4497.

Podlisny MB, Mammen AL, Schlossmacher MG, Palmert MR, Younkin SG, Selkoe DJ (1990) Detection of soluble forms of the $\beta$-amyloid precursor protein in human plasma. Biochem Biophys Res Commun 167:1094-1101.

Podlisny MB, Tolan D, Selkoe DJ (1991) Homology of the amyloid $\beta$-protein precursor in monkey and human supports a primate model for $\beta$-amyloidosis in Alzheimer's disease. Am J Pathol 138:14231435 .

Ponte P, Gonzalez-DeWhitt P, Schilling J, Miller J, Hsu D, Greenberg B, Davis K, Wallace W, Lieberburg I, Fuller F, Cordell B (1988) A new A4 amyloid mRNA contains a domain homologous to serine proteinase inhibitors. Nature 331:525-527.

Probst A, Brunnschweiter H, Lautenschlager C, Ulrich J (1987) A special type of senile plaque, possibly an initial stage. Acta Neuropathol (Berl) 74:133-141.

Robakis NK, Ramakrishna N, Wolfe G, Wisniewski HM (1987) Molecular cloning and characterization of a cDNA encoding the cerebrovascular and the neuritic plaque amyloid peptides. Proc Natl Acad Sci USA 84:4190-4194.

Robinson AP, White TM, Mason DW (1986) Macrophage heterogeneity in the rat as delineated by two monoclonal antibodies MRC 
Ox-41 and MRC Ox-42, the latter recognizing complement receptor type 3. Immunology 57:239-247.

Rozemuller JM, Eikelenboom P, Stam FC, Beyreuther K, Masters C (1989) A4 protein in Alzheimer's disease: primary and secondary cellular events in extracellular amyloid deposition. J Neuropathol Exp Neurol 48:674-691.

Rumble B, Retallack R, Hilbich C, Simms G, Multhaup G, Martins R, Hockey A, Montgomery P, Beyreuther K, Masters C (1989) Amyloid A4 protein and its precursor in Down's syndrome and Alzheimer's disease. N Engl J Med 320:1446-1452.

Saiki RK, Gelfand DH, Stoffel S, Scharf SJ, Higuchi R, Horn GT, Mullis KB, Ehrlich HA (1988) Primer directed enzymatic amplification of cDNA with thermostable DNA polymerase. Science 239:487-491.

Saitoh T, Sundsmo M, Roch JM, Kimura N, Cole G, Schubert D, Oltersdorf T, Schenk DB (1989) Secreted form of amyloid $\beta$ protein precursor is involved in the growth regulation of fibroblasts. Cell 58 615-622.

Schechter R, Yen SY, Terry RD (1981) Fibrous astrocytes in senile dementia of the Alzheimer type. J Neuropathol Exp Neurol 40:95101 .

Schubert D, Jin L-W, Saitoh T, Cole G (1989a) The regulation of amyloid $\beta$ protein precursor secretion and its modulatory role in cell adhesion. Neuron 3:689-694.

Schubert D, LaCorbiere M, Saitoh T, Cole G (1989b) Characterization of an amyloid $\beta$ precursor protein that binds heparin and contains tyrosine sulfate. Proc Natl Acad Sci USA 86:2066-2069.

Selkoe DJ (1989) Molecular pathology of amyloidogenic proteins and the role of vascular amyloidosis in Alzheimer's disease. Neurobiol Aging 10:387-395.

Selkoe DJ, Abraham CR, Podlisny MB, Duffy LK (1986) Isolation of low-molecular-weight proteins from amyloid plaque fibers in $\mathrm{Alz}$ heimer's disease. J Neurochem 146:1820-1834.

Selkoe DJ, Podlisny MB, Joachim CL, Vickers EA, Lee G, Oltersdorf $T$ (1988) $\beta$-Amyloid precursor protein of Alzheimer disease occurs as 110 - to 135 -kilodalton membrane-associated proteins in neural and nonneural tissues. Proc Natl Acad Sci USA 85:7341-7345.

Shivers BD, Hilbich C, Multhaup G, Salbaum M, Beyreuther K, Seeburg PH (1988) Alzheimer's disease amyloidogenic glycoprotein: expression pattern in rat brain suggests a role in cell contact. EMBO J 7:1365-1370.

Siman R, Card JP, Nelson RN, Davis LG (1989) Expression of $\beta$-amyloid precursor protein in reactive astrocytes following neuronal damage. Neuron 3:275-285.

Sinha S, Dovey HF, Seubert P, Ward JP, Blacher RW, Blaber M, Bradshaw RA, Arici M, Mobley WC, Lieberburg I (1990) The protease inhibitory properties of the $\Lambda$ lzheimer's $\beta$-amyloid precursor protein. J Biol Chem 265:8983-8985.

Sisodia SS, Koo EH, Beyreuther K, Unterbeck A, Price DL (1990) Evidence that $\beta$-amyloid protein in Alzheimer's disease is not derived by normal processing. Science 248:492-495.

Smith RP, Higuchi DA, Broze GJ Jr (1990) Platelet coagulation factor XIa-inhibitor, a form of Alzheimer amyloid precursor protein. Science 248:1126-1128.

Tagliavini F, Giaccone G, Frangione B, Bugiani O (1988) Preamyloid deposits in the cerebral cortex of patients with Alzheimer's disease and nondemented individuals. Neurosci Lett 93:191-196.

Tanaka S, Shiojiri S, Takahashi Y, Kitaguchi N, Ito H, Kameyama M, Kimura J, Nakamura S, Ueda K (1989) Tissue-specific expression of three types of $\beta$-protein precursor mRNA. Biochem Biophys Res Commun 165:1406-1414.

Tanzi RE, Gusella JF, Watkins PC, Bruns GAB, St George-Hyslop PH, Van Keuren ML, Patterson D, Pagan S, Kurnit DM, Neve RL (1987) Amyloid $\beta$-protein gene: cDNA, mRNA distribution, and genetic linkage near the Alzheimer locus. Science 235:880-884.

Tanzi RE, McClatchey AI, Lamperti ED, Villa-Komaroff LL, Gusella JF, Neve RL (1988) Protease inhibitor domain encoded by an amyloid protein precursor mRNA associated with Alzheimer's disease. Nature 331:528-530.

Van Nostrand WE, Cunningham DD (1987) Purification of protease nexin II from human fibroblasts. J Biol Chem 262:8508-8514.

Van Nostrand WE, Wagner SL, Suzuki M, Choe BH, Farrow JS, Geddes JW, Cotman CW, Cunningham DD (1989) Protease nexin-II, a potent anti-chymotrypsin inhibitor, shows identity to amyloid $\beta$-protcin precursor. Naturc 341:546-549.

Van Nostrand WE, Schmaier AH, Farrow JS, Cunningham DD (1990) Protease nexin-II (amyloid $\beta$-protein precursor): a platelet $\alpha$-granule protein. Science 248:745-748.

Weidemann A, Konig G, Bunke D, Fischer P, Salbaum M, Masters CL, Beyreuther K (1989) Identification, biogenesis, and localization of precursors of Alzheimer's disease A4 amyloid protein. Cell 57:115126.

Wisniewski HM, Wegiel J, Wang KC, Kujawa M, Lach B (1989) Ultrastructural studies of the cells forming amyloid fibers in classical plaques. Can J Neurol Sci 16:535-542.

Yamada T, Sasaki H, Furuya H, Miyata T, Goto T, Sakaki Y (1987) Complementary DNA for the mouse homolog of the human amyloid beta protein precursor. Biochem Biophys Res Commun 149:665-671.

Yamaguchi H, Hirai S, Morimatsu M, Shoji M, Harigaya Y (1988) Diffuse type of senile plaques in the brains of Alzheimer-type dementia. Acta Neuropathol (Berl) 77:113-119. 